\title{
Research on the New Mode of College English Teaching based on Interactive Teaching and Flip-up Classroom
}

\author{
Dapeng Wang ${ }^{1}$ \\ ${ }^{1}$ Teaching and Research Institute of Foreign Languages, Bohai University, Jinzhou 121013, China.
}

Keywords: New Mode, English Teaching, Interactive Teaching, Flip-up Classroom.

\begin{abstract}
This paper proposes the research on the new mode of college English teaching based on the interactive teaching and flip-up classroom. Experiential teaching dares to break the main status of teachers in the traditional teaching methods, improve students' status in the learning process, and establish the equal relationship between teachers and students, establishes the open style teaching environment, lets each students all be able to participate in the teaching truly in the process. In the teaching of English, we should pay attention to the teaching of basic knowledge, art design classroom teaching, teachers in the basic knowledge of teaching should be based on the way students think and characteristics. To this level, this paper proposes the novel paradigm for the college English teaching which will then promote the further development.
\end{abstract}

\section{Introduction}

The main purpose of this course is to improve the English skills of college students, to strengthen the language system of university students, to enhance the employment competitiveness of university graduates and to promote the development of college students' personality, and to require students to master oral English and English writing skills to master direct use of English and foreign exchange and enhance the comprehensive quality of Chinese students. The university English teaching goal raises the student English synthesis application ability, specially hears ability, will cause the student in the future work, the life and the society associates can use English to carry on oral and the written communication that will sharpen the communication ability and will adapt our country present stage economy development and the international exchange need, from this also to our country university graduates' English proficiency proposed a higher request, simultaneously proposed the new challenge to the university English teaching.

Based on the review, current challenges and principles of the English teaching can be summarized as the listed aspects. (1) The three factors such as linguistic competence, pragmatic competence, and the ability to discard and discard the penetrating power, are mutually independent and interrelated that influence and complement each other. (2) Pragmatic Failures in intercultural Communication is a common phenomenon, which is rooted in the cultural differences of the interference caused by the cross-cultural communication. (3) Use social failures is because the two basic sides of the cultural background of different as entertainment to comply with different rules of communication as a result of errors. It is believed that the language used in basic mistakes with the language and social use with mistakes with the communicative community rules but both categories were not absolute that is always present in the coincidence. (4) The related university English concrete reform direction and the measure have initiated the education administration department and English teach the educational world the widespread discussion. The university English education reform needs the theory proof that needs to innovate boldly and needs to profit from university's educational reform practice.

In the teaching of English, we should pay attention to the teaching of basic knowledge, art design classroom teaching, teachers in the basic knowledge of teaching should be based on the way students think and characteristics, through various channels, the knowledge structure pave the way students thinking. To guide the students to think, to encourage students to think from different angles, while learning knowledge, training, thinking, thinking method to guide learning knowledge. Teacher's goal is not pure enhances student's academic record, but is makes every effort to achieve the student study to have the development, studies exactly, studies passes achieved reads thinks unifies, stimulates the 
student to ponder positively that, found the problem, proposed the question and solved the question ability. Flip-up classroom as the new form of education is being adopted by more and more people, in the figure one we show the comparison of the traditional and the flip-up classroom and in the later sections, we will then discuss the issues in detail.

\begin{tabular}{|c|c|c|c|}
\hline \multicolumn{2}{|c|}{ Traditional Classroom } & \multicolumn{2}{|c|}{ Flipped Classroom } \\
\hline Activity & Time & Activity & Time \\
\hline Warm-up Activity & $5 \mathrm{~min}$ & Warm-up Activity & $5 \mathrm{~min}$ \\
\hline $\begin{array}{l}\text { Go over previous } \\
\text { night's homework }\end{array}$ & $10 \mathrm{~min}$ & $\begin{array}{l}\text { Q\&A time } \\
\text { independent learning }\end{array}$ & $10 \mathrm{~min}$ \\
\hline Lecture new content & $30 \mathrm{~min}$ & $\begin{array}{l}\text { Practice activities } \\
\text { - Skits }\end{array}$ & $45 \mathrm{~min}$. \\
\hline Practice & $15 \mathrm{~min}$. & $\begin{array}{l}\text { - Debates } \\
\text { - Questions }\end{array}$ & \\
\hline \multirow{2}{*}{$\begin{array}{l}\text { Homework: } \\
\text { Independent practice } \\
\text { and/or lab activity }\end{array}$} & \multirow[t]{2}{*}{$30 \mathrm{~min}}$. & - Demonstrations & \\
\hline & & $\begin{array}{l}\text { Homework: } \\
\text { Refresh Learning } \\
\text { Prepare for next class }\end{array}$ & $\begin{array}{l}10 \mathrm{~min} . \\
20 \mathrm{~min} .\end{array}$ \\
\hline
\end{tabular}

Fig. 1 The Comparison of the Traditional and Flip-up Classroom

\section{Our Proposed Methodology}

English Interactive Teaching. As a new way of teaching, experiential teaching appears in university classroom, which effectively promotes the change of thought, way and concept of university teaching, and avoids some problems in the traditional English teaching. Since long ago the foreign language teaching often only takes the pure language and writing the classroom instruction, its teaching method and the goal only base on the sole writing modality, extremely little unifies the non-writing other modality form to launch the classroom instruction and the appraisal. Along with the human relations informationization and the digitized popularization, the multiple states have affected inevitably the classroom instruction pattern. We can summarize the advantages of the interactive teaching as listed.

- Experience type teaching way even more multiplex. Experiential teaching requires a lot of teaching content must be extended to expand, it also requires students to use the network of independent learning, so that students according to their actual situation to determine their learning time and progress, so as to improve efficiency and cultivate self-learning ability.

- Experiential teaching can promote people's all-round development. Teaching experience will be the theme and life learning combined with the practical experience can let students feel and understand the social ideological and moral requirements, so as to form the correct values and good psychological and moral quality and promote the all-round development of people.

- Experiential teaching can cultivate students' subjective initiative in learning. The experiential learning is to transform their students as the protagonists in the classroom activities to develop students' self-learning ability and the innovative capabilities to enable the students to actively participate in the classroom, enhanced between the teacher and the exchange and dialog, more effective learning.

Flip-up Classroom Teaching Mode. In 2011, the "flip-flop classroom" is a new form of education and teaching, which overturns the classroom teaching mode in the traditional sense. This class includes creating instructional videos and organizing classroom activities. The advantages are: the video is short and the teaching information is clear and clear. The innovation of teaching mode needs us to explore continuously. As a college English teacher, we need to learn from foreign advanced educational concepts, combined with the specific circumstances of China students, the creation of a China with the English classroom teaching mode, cultivating the ability of students, to promote the sharing of high-quality educational resources shown as the figure 2.

Under this basis, Chinese flip-up classroom teaching mode should contain the following items. (1) Create instructional video. Teachers create instructional videos based on the teaching objectives, key 
and difficult points of each lesson. (2) For the number of the pre-class exercises and the degree of difficulty, teachers should be designed to help students use the old knowledge to complete the transition to new knowledge. Teachers need to use the teaching management platform to encourage students to encounter difficult problems through the teaching platform and other students and teachers to ask. (3) The union studies the content, arranges the student to do extends the practice, by individual or group's form in classroom through or multimedia introduction certain characters, thing or social phenomenon in kind and so on, and mentions own true feelings true feelings.

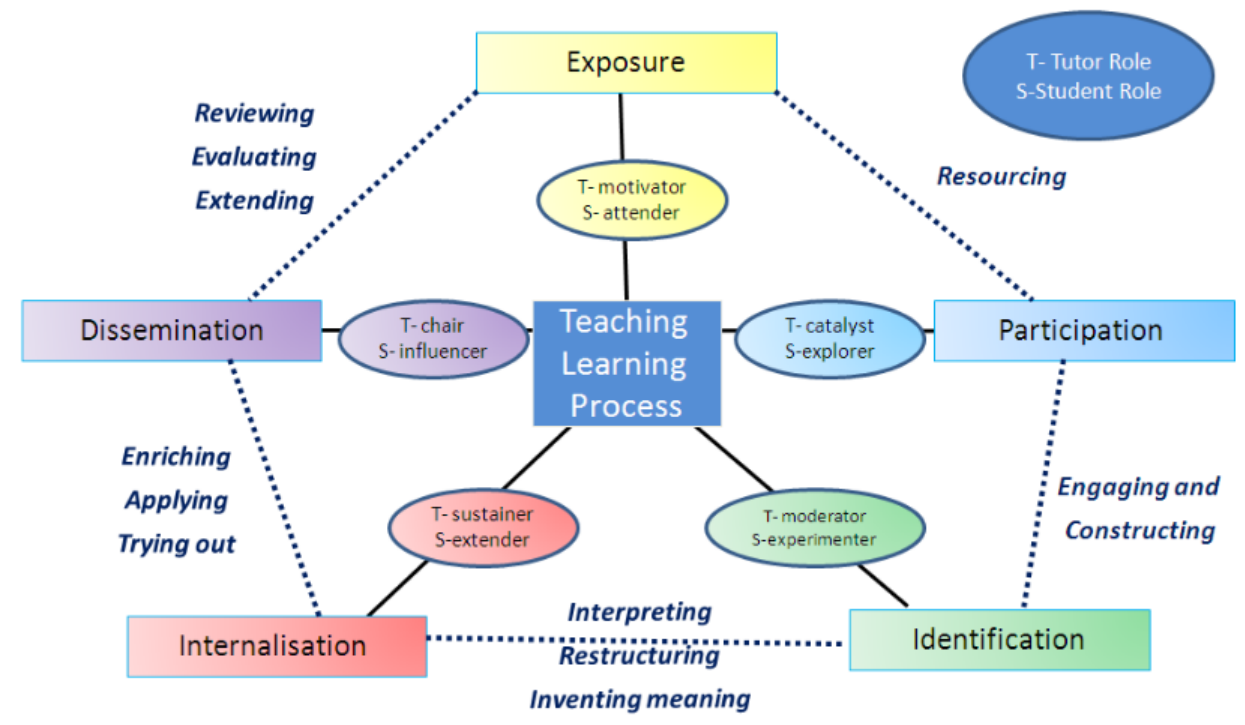

Fig. 2 Flip-up Classroom Teaching Mode Demonstration

English Reading Teaching. In the foreign language education, the reading importance is more prominent. Reading is a complex activity, including cognition, culture, language, factors and so on study strategy, language. English reading duty is arduous, not only it is one of important language skills which English learner needs to grasp, moreover also is the learner obtains the language input the main way. The purpose of reading the teaching, that is, student quickly and accurately reading ability, in order to achieve this goal, the core of reading teaching is to cultivate the students 'thinking ability, and the three dimensions are the dimensions of the language knowledge, information knowledge and discourse knowledge. The reading skills are actually students' fast and accurate understanding of the article's catalyst. In the teaching of English reading, decoding is the foundation, understanding is the key. Decoding is a student's vocabulary and the grammar knowledge, and understanding is a cognitive structure that already exists in the student's mind. The so-called schema is the knowledge structure that the reader originally acquired, that is, the background knowledge of the reader's brain, which refers to the system and the organization's knowledge network structure. Under this basis, the principles of the reading education can be summarized as follows.

- Reading understood the process which the process is which in the student brains scheme and the language material provide between the information affects mutually, when student's provides brains in related scheme and the language material information establishes relates that can obtain the significance which the article must transmit.

- Content schema is the understanding degree of students' reading materials and contents, and plays a key role in the English reading comprehension. English language teaching should be combined with cultural knowledge teaching, and it is more important to have the background knowledge on the topic of the article than to master the vocabulary knowledge.

- The scheme is students in the form of knowledge of the genre and textual structures of the knowledge of the English reading comprehension. Enhance students' English chapter in the organization and the author chapter policy awareness is also very important.

The Suggestions for the Further English Teaching. English teaching language artistry first requires teachers to articulate, and pronunciation should be correct, full, teaching language to pay attention to cadence, speed should be moderate, intonation to rhythm, and the appropriate use of body 
language, vivid and rich language conducive to the creation of harmonious and pleasant classroom atmosphere, to improve students' interest in learning English, to strengthen the interaction between teachers and students to teach the language of science is the use of English language teachers to be accurate, clear, rich content. But speaking of university's university foreign language teaching work above only has the foreign language teaching rule research which mentioned also by far insufficiently. Although the university foreign language teaching on the main body is the university foreign language teacher cooperates the realization teaching goal process with the non-English specialized student, this process occurs by no means under the perfect condition, but is the multi-level multi-factor influence, in particular under the foreign language teaching reform correlation policy influence, and that the university interior each kind of factor influence, may say directly is a systems engineering.

Therefore, we give the following suggestions. (1) Note the use of incentive art. In the use of the teaching language, teachers should pay special attention to tone to mildly, moderate, eliminate or reduce the students' nervousness. (2) Try to organize classroom teaching in English. Whether it is the classroom language, language teaching, language or communication between teachers and students' feedback language, teachers should try to use English to communicate with students, and through the body language and other auxiliary means to help students understand the language teaching.

\section{Summary}

This paper proposes the research on the new mode of the college English teaching based on the interactive teaching and flip-up classroom. As a new teaching method, experiential teaching is a new teaching method in college English teaching. It is an important reform measure in our country. Quality education, more emphasis on cultivating students' comprehensive learning ability and improve the overall quality of the students, experiential teaching conforms to this development needs to meet the requirements of China's reform of college English learning. Experiential teaching dares to break the main status of teachers in the traditional teaching methods, improve students' status in the learning process, and establish the equal relationship between teachers and students, establishes the open style teaching environment, lets each students all be able to participate in the teaching truly in the process, fully arouses the enthusiasm and the initiative in the study process which the student studies, thus enhances the student language practical application ability.

\section{References}

[1] Dongchun, C. H. E. N. "Study on the business-based college English teaching model for language performance improvement [J]." Foreign Language World 4 (2013): 005.

[2] Appleman, Deborah. Critical encounters in secondary English: Teaching literacy theory to adolescents. Teachers College Press, 2014.

[3] Ma, W. L., and Y. Jiang. "A Research into the Problems and Their Causes of Non-Language Major Tertiary-Level Students’ English Listening in Blended Teaching Model." Foreign Language and Literature 1 (2013): 138-143.

[4] GAO, Qiang, and Lin LIU. "Investigating college English teachers' beliefs in listening teaching and their relationships with teaching practices [J]." Foreign Language World 2 (2013): 004.

[5] Liu, Bo. "Application of Associative Teaching Strategy in College English Vocabulary Teaching." Open Journal of Modern Linguistics 6.03 (2016): 225. 